\title{
Technology Roadmap for Wastewater Reuse in Petroleum Refineries in Brazil
}

\author{
Felipe Pombo, Alessandra Magrini and Alexandre Szklo \\ Federal University of Rio de Janeiro, Energy Planning Program \\ Brazil
}

\section{Introduction}

Because of the planned expansion of Brazil's refining capacity called for in the government's energy policy and the scenario of stress on water resources, it is necessary to design the country's new refineries so as to minimize water consumption and maximize reuse of effluents.

Existing refineries are large water consumers. In 2009, Brazilian refineries consumed 254,093 $\mathrm{m}^{3}$ / day of water (estimated from the water consumption index of Petrobras refineries, of $0.9 \mathrm{~m}^{3}$ water/ $\mathrm{m}^{3}$ of oil) (Amorim, 2005). Empresa de Pesquisa Energética - EPE ("Energy Research Company"), a federally owned company that is part of the Ministry of Mines and Energy, forecasts an increase of $79 \%$ in Brazilian refining capacity with the construction of new refineries by 2030 (EPE, 2007). Some of them are planned for the Northeast region, which suffers from water shortage. While Brazil as a whole is blessed with water, having roughly $13 \%$ of the planet's freshwater reserves (Mierzwa \& Hespanhol, 2005), these resources are very unevenly distributed, with some regions plagued by shortages (arid and semi-arid regions) and others blessed with abundant water. Finally, although the country's industrial heartland, the state of São Paulo, and the center of its oil industry, the state of Rio de Janeiro, both are in the country's semi-tropical region, they still face problems of water shortages due to high demand, causing conflicts among watershed users.

The methods to reduce water consumption are conservation, recycling and reuse. Among the three, water conservation requires the least effort and investment costs. It involves the rational use of water by industry, incorporating measures to prevent physical losses and improve operations (Matsumura \& Mierzwa, 2008). Recycling (with regeneration) refers to the use of treated wastewater at the place of origin. Finally, water reuse can occur in the following forms: a) direct reuse of wastewater in other processes, when the level of contamination does not interfere in the next process; and b) with regeneration, which is reuse of treated effluent in different processes than the original one (Wang \& Smith, 1994).

An important energy efficiency program was launched in 1992 by the U.S. Environmental Protection Agency, called Energy Star. As part of this program, a guide was issued focused on the refinery industry (Worrell \& Galitsky, 2005). However, this document only covers energy use by refineries. There is a need for a similar document on efficient water use by refineries. Therefore, against the backdrop depicted above of unevenly distributed and locally insufficient water resources, a technology roadmap for Brazilian refineries is important. 
There is a need to differentiate between treatment of refinery wastewater for discharge into water bodies and for reuse in other refinery units. The second case requires more advanced treatment systems, because the quality requirements are higher. Some examples of treatment techniques are reverse osmosis and reverse electrodialysis, with cost being the main barrier to widespread adoption of both (see Section 3). The first case requires more rudimentary treatment systems, as presented in Section 2.

This chapter addresses the problem identified above by presenting a technology roadmap for reuse of the effluents produced by Brazilian oil refineries, which have a great need to minimize water use, a need that can be met through the significant recent technological advances. Section 2 presents the conventional treatment of refinery wastewater while Section 3 lays out the proposed technology roadmap for wastewater treatment for reuse by refineries, analyzing the following technologies: membranes, membrane bioreactors (MBRs), reverse osmosis, reverse electrodialysis, ion exchange and advanced oxidative processes. Section 4 presents estimates of the costs and perspectives for application of these technologies in Brazil. Finally, Section 5 presents the conclusions of this chapter.

\section{Conventional treatment of oil refinery effluents}

The main contaminants in wastewater from refineries are oils and greases, which can exist in three forms: free (droplets with diameters larger than $150 \mu \mathrm{m}$ ), dispersed (droplets in the range of 20 to $150 \mu \mathrm{m}$ ) and emulsified (droplets smaller than $20 \mu \mathrm{m}$ ) (Cheryan \& Rajagopalan, 1998).

The conventional methods to treat oily wastewater include (Cheryan \& Rajagopalan, 1998):

- Gravity separation;

- Dissolved air flotation;

- Demulsification;

- Coagulation;

- Flocculation;

- Biological treatment.

Gravity separation is an efficient and low-cost method to remove free oil from wastewater (Cheryan \& Rajagopalan, 1998). It is the first step of treatment of oily effluents at refineries. API (American Petroleum Institute) separators are the main such devices. This category also includes parallel and corrugated plate separators.

The process for oil/water separation by gravity includes two mechanisms: decantation and coalescence. The first mechanism occurs according to Stokes' Law (Equation (1)), while the second occurs through interactions at the interfaces of the dispersed oil droplets with the surrounding water (Jaworski, 2009). According to Equation (1), the smaller the oil droplet diameter, the more time it will take to separate the oil from the water.

$$
\mathrm{Vr}=\mathrm{gDo}^{2}(\rho \mathrm{w}-\rho \mathrm{o}) / 18 \mu \mathrm{a}
$$

Here $\mathrm{Vr}$ is the velocity of rise, $\mathrm{g}$ is the acceleration of gravity, $\rho \mathrm{w}$ and $\rho$ are the density of water and oil, respectively, Do is the oil droplet diameter and $\mu$ a is the absolute viscosity of water.

In API separators, part of the oil accumulates at the liquid's surface because of its lower specific gravity than water, but oil in emulsion and small oil droplets (with diameters under $150 \mu \mathrm{m})$ are not separated. The part that rises is skimmed off, while another fraction, 
consisting of oil-soaked solids, settles to the bottom of the separator, where it is also removed. To prevent the formation of very small particles that cannot be separated by this method, it is important that the wastewater in the outlet pipes and drainage systems be carefully conveyed, to avoid generating turbulence, such as that caused by pumps or sudden falls. It is also important to avoid the presence of emulsifiers (Braile, 1979).

In general, refineries rely on the design standards of the manual entitled "Disposal of Refinery Wastes", according to which API separators can be installed to work in series with parallel plate interceptors (PPI) or corrugated plate interceptors (CPI), the last of which are more modern and besides separating oil from the water, can also remove part of the solid material. With PPI or CPI separators, it is possible to remove oil droplets with sizes down to $75 \mu \mathrm{m}$, representing an additional recovery of from 10 to $30 \mathrm{mg}$ of oil per liter (Braile, 1979). PPIs and CPIs improve the gravity separation because this process is based on the droplets reaching the continuous phase before leaving the separator, which is enhanced by increasing the specific surface area and reducing the height through which the oil droplets must rise before reaching the surface. Both of these devices accomplish this improvement (Jaworski, 2009).

Flotation is a technique initially used in ore processing for selective separation of one type of solid from another, through the different specific gravities of the desired and undesired solids. But with recent advances, flotation devices are increasingly being used for treatment of industrial effluents. According to Rubio et al. (2002), these advances include the higher efficiency of modern equipment, new separation schemes, selective recovery of valuable ions (such as gold, palladium and silver) and lower generation of sludge.

Dissolved air flotation (DAF) is the technique most often used to treat industrial effluents, particularly oil refinery wastewater. It works through the formation of micro-bubbles, by pre-saturating the effluent with air at pressures of 3 to 6 atm and then rapidly reducing this pressure to $1 \mathrm{~atm}$. By this process, the solution first becomes oversaturated under pressure and then when the pressure drops the air forms micro-bubbles with diameters of between 50 and $100 \mu \mathrm{m}$ through nucleation/cavitation, rupturing the fluid's structure (Rubio et al., 2002; Luz et al., 2002).

Since oil is hydrophobic, with weak affinity for water, it tends to join with the air microbubbles and is carried to the top of the device. This process can be enhanced by the addition of surfactants, which work by controlling the surface properties of the oil droplets, making them more hydrophobic and easier to separate out selectively (Luz et al., 2002; Al-Shamrani et al., 2002). The most important factors in designing and dimensioning industrial DAF systems are the characteristics of the saturator, the air/solids ratio, the hydraulic discharge and the micro-bubble generation system (Luz et al., 2002).

Conventional biological treatment is not able to remove all organic compounds to satisfy wastewater discharge standards. Therefore, pretreatment through biological purification is necessary. Among these processes, dissolved air flotation is the most common (Hami et al., 2007). These authors studied the effect of adding powdered activated carbon on the removal of pollutants in terms of BOD (biological oxygen demand) and COD (chemical oxygen demand) in a pilot-scale dissolved air flotation unit with a conical bottom, aiming to improve efficiency in adsorption of pollutants. They found that BOD and COD declined considerably with the addition of the activated carbon to the wastewater, and that increasing the quantity of activated carbon enhanced the pollutant removal efficiency (in \%) for both BOD and COD. 
Primary separators are used to break oil-water emulsions, allowing the demulsified oil to be separated from the water. Chemical methods (mainly addition of ferric and aluminum salts) are most commonly utilized. In this case, the process in general consists of rapid mixture of chemical coagulants with the wastewater, followed by flocculation and flotation/decantation. In turn, physical methods include heating, centrifugation, ultrafiltration and membrane processes (Yang, 2007).

There are various methods of breaking down emulsions and promoting coalescence of the oil droplets, after which they can be separated by gravity differential methods (Braile, 1979). Heating is used to reduce viscosity, accentuate density differences and weaken the interfacial films that stabilize the oil phase (Cheryan \& Rajagopalan, 1998). Distillation is employed in some particularly resistant emulsions. Adjustment of the $\mathrm{pH}$ can destroy the protective colloid and permit sedimentation, which in some cases can also be achieved by aeration or chemical coagulation. Centrifugation increases the sedimentation force and can be used alone or together with heat or addition of chemical products. Filtration with diatomaceous earth or another element to assist filtration normally works well (Braile, 1979). In the case of chemical treatment, it is important to choose the right mixture of chemicals and optimize the process to reduce operating costs and enhance effectiveness (Cheryan \& Rajagopalan, 1998).

Yang (2007) explained the mechanism of breaking down water-oil emulsions with electrochemical methods (electrochemical coagulation). This consists of an electrochemical reactor formed by iron electrodes (negative cathode and positive anode). During electrolysis, a DC voltage is applied to the electrodes, dissolving ferrous ions (Fe(II)) at the anode. These ions are in turn oxidized into ferric ions (Fe(III)), destabilizing the emulsion:

$$
\begin{gathered}
\mathrm{Fe}_{(\mathrm{s})} \rightarrow \mathrm{Fe}_{(\mathrm{aq})^{2+}}+2 \mathrm{e}^{-} \rightarrow \mathrm{Fe}_{(\mathrm{aq})^{3+}+3 \mathrm{e}^{-}} \\
2 \mathrm{H}_{2} \mathrm{O}+2 \mathrm{e}^{-} \rightarrow 2 \mathrm{H}_{2(\mathrm{~g})}+2 \mathrm{OH}_{(\mathrm{aq})^{-}} \\
\mathrm{Fe}_{(\mathrm{aq})^{3+}}+3 \mathrm{OH}_{(\mathrm{aq})^{-}} \rightarrow \mathrm{Fe}(\mathrm{OH})_{3(\mathrm{~s})} .
\end{gathered}
$$

The coagulation is promoted by the addition of inorganic multivalent electrolytes, in general containing hydrosoluble cations, such as $\mathrm{Al}^{3+}$ and $\mathrm{Fe}^{3+}$ (Luz et al., 2002), and occurs when the attractive surface forces overcome the repulsive forces, allowing clots to form. The DLVO theory, named after the scientists who developed it independently (Derjaguin \& Landau, 1941 and Verwey \& Overbeek, 1948), explains the stability of colloid systems. This theory is based on the energy variations observed due to the aggregation of particles, considering only the Van der Waals attraction and electrostatic repulsion (Luz et al., 2002). The potential interaction energy $\left(\mathrm{V}_{\mathrm{T}}\right)$ is obtained by the balance of attractive $\left(\mathrm{V}_{\mathrm{A}}\right)$ and repulsive $\left(V_{R}\right)$ interactions, as shown in Equation (5),

$$
\left(\mathrm{V}_{\mathrm{T}}=\mathrm{V}_{\mathrm{A}}+\mathrm{V}_{\mathrm{R}}\right)
$$

Aggregation occurs when $V_{A}>V_{R}$, while dispersion occurs when $V_{A}<V_{R}$ (Luz et al., 2002). In the case of two identical spherical particles, Equations (6) and (7) hold:

$$
\begin{gathered}
\mathrm{V}_{\mathrm{A}}=-\mathrm{Aa} / 12 \mathrm{~d} \\
\mathrm{~V}_{\mathrm{R}}=2 \mathrm{C}^{2} \mathrm{a} \zeta^{2} \exp (-\mathrm{kd}),
\end{gathered}
$$


where A is the Hamaker constant, a is the radius of the particles, $\epsilon$ is the permittivity of the solution, $\zeta$ is the zeta potential and $\mathrm{k}$ is the Debye-Huckel parameter, or the inverse of the double electric layer thickness.

Flocculation involves the addition of a polymer, called a flocculant, which promote the aggregation of fine particles to form flakes. The polymers can be classified in three ways: by origin (natural, modified or synthetic), molecular weight (low or high molecular weight) and electrical charge (neutral, anionic or cationic). The aggregates can be formed independently of the structural forces involved. The efficiency of the process depends, among other factors, on the choice of the proper flocculant, the way it is applied, the chemical environment, the system's hydrodynamics and the sizes of the particles (Luz et al., 2002).

Biological treatment is particularly useful to remove biodegradable organic matter from refinery wastewater. The main techniques are aerated lagoons, activated sludge and biodiscs.

Aerated lagoons are artificial basins built to hold large volumes of effluents. They can be built above or below the original land surface. The aeration is not strictly natural; it is enhanced by the artificial introduction of oxygen, required by the organisms that decompose the soluble organic and fine particulate matter (Matos, 2005).

In aerated lagoons, the aeration energy defines whether the liquid mass will be held in total or partial suspension. These lagoons can be classified as facultative aerated lagoons or suspension mixed lagoons. In the first case, the formation and separation of biological flakes occurs in the lagoon itself, because the energy supplied to the aeration equipment is limited, ranging between 0.75 and $1.5 \mathrm{~W} / \mathrm{m}^{3}$, which is insufficient to keep the sludge in suspension, so that solids settle in the lagoon. In the second case, the objective is to convert the soluble biodegradable organic material into biomass that can settle as sludge, which is done in secondary sedimentation ponds. The formation of biological flakes also occurs in the lagoon, but the aeration energy is greater than or equal to $3.0 \mathrm{~W} / \mathrm{m}^{3}$, preventing the sedimentation of solids, which as stated, occurs in a secondary sedimentation pond. The removal rate in aerated lagoons is in general between 80 and 90\% for total suspended solids (TSS), 65 and $80 \%$ for COD and 50 and $95 \%$ for BOD, depending on the type of setup (Matos, 2005).

The activated sludge process is carried out in two main compartments: the aeration tank and the clarification tank (Figure 1). Microorganisms (specific types of bacteria) are used for biological degradation of the effluent. Some bacteria need an environment rich in oxygen (aerobic), while others need one poor in oxygen (anaerobic). The conversion products are water, carbon dioxide, nitrogen and dead microorganisms (called surplus sludge). In the aeration tank the wastewater and activated sludge are mixed so that the conversion reaction can occur. Then the activated sludge is separated out of the liquid in the other compartment by sedimentation. Most of the sludge precipitated out is returned to the aeration tank to repeat the process, but an excess portion is purged. Without this purge, the activated slugde concentration would increase too much, reducing the sedimentation efficiency in the clarification tank (Oever, 2005).

In general treatment in a series of aerated lagoons is less expensive in terms of initial investment in equipment, but requires sufficient space. An activated sludge separation unit requires less area, but has higher operating cost and performs better. More demanding clean-up standards regarding removal of certain recalcitrant pollutants, mainly biomass, are only attained with units that enable extended residence times. Through knowledge of the 
phenomena that govern the transformations of the biodegradable and oxidizable compounds is important to assure good performance of new biological treatment units or to improve the performance of existing ones. Modeling these complex phenomena in advance is an important step in this sense (Piras, 1993).

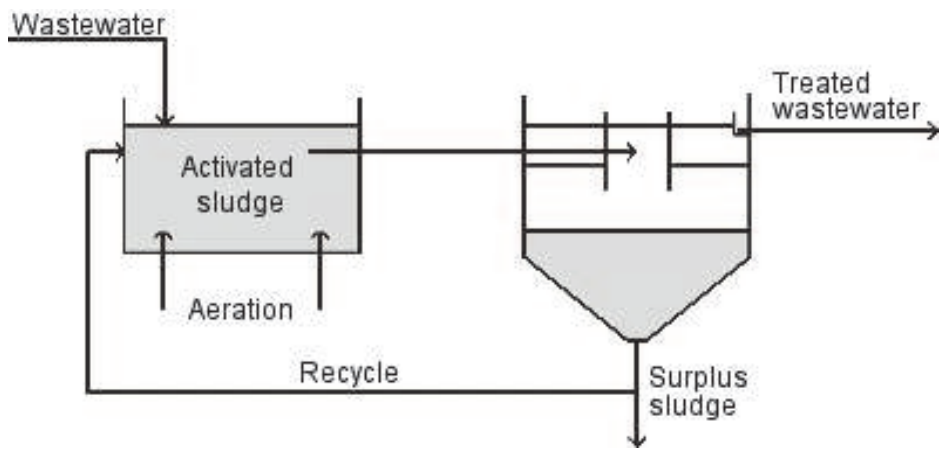

Fig. 1. Diagram of a conventional activated sludge process (Oever, 2005).

Biodiscs are cylindrical structures of plastic discs supported by a central axis. These structures are mounted horizontally above tanks so that about 30 to $40 \%$ of each disc is submersed in the liquid during rotation. The most common configuration is a disc diameter

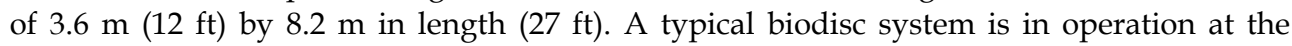
REFAP refinery in Brazil. It consists of four sets of discs. In the first set, the microorganisms, with adequate conditions in terms of oxygen, substrate, $\mathrm{pH}$, ammonia and phosphate, attach themselves to the discs and start to grow, forming a biofilm. This biofilm uses the oxygen and organic carbon dissolved in the wastewater, removing the organic load by the action of heterotrophic bacteria. In the second set, the biofilm promotes nitrification by the action of nitrosomonas and nitrobacter bacteria. In the third set, the biofilm promotes denitrification by the action of specific bacteria. Finally, in the fourth set the process works as in the first set, to remove the residual organic load from the addition of methanol in the denitrification process (Ferreira et al., 2000).

\section{Technological roadmap for wastewater treatment at oil refineries aiming at reuse}

The objective of this chapter is to study the best available techniques (BATs) for treatment of oil refinery wastewater for purposes of reuse.

The expression "best available techniques" is defined in Section 5 of the U.S. Environmental Protection Agency Acts, 1992 and 2003, and Section 5(2) of the Waste Management Acts, 1996 to 2005, as the "most effective and advanced stage in the development of an activity and its methods of operation, which indicate the practical suitability of particular techniques for providing, in principle, the basis for emission limit values designed to prevent or eliminate or, where that is not practicable, generally to reduce an emission and its impact on the environment as a whole, where best in relation to techniques means the most effective in achieving a high general level of protection of the environment as a whole, available techniques means those techniques developed on a scale which allows implementation in the 
relevant class of activity under economically the technically viable conditions, taking into consideration the costs and advantages, whether or not the techniques are used or produced within the State, as long as they are reasonably accessible to the person carrying out the activity, and techniques includes both the technology used and the way in which the installation is designed, built, managed, maintained, operated and decommissioned" (EPA, 2008).

In designing an advanced treatment unit for secondary wastewater, the following aspects should be considered (Teodosiu et al., 1999):

- complete characterization of the effluent;

- the level of dissolved solids that can be reduced by coagulation-flocculation, sedimentation and/or filtration with sand, microfiltration or ultrafiltration;

- the dissolved organic matter that can be removed by adsorption with activated carbon, chemical oxidation, reverse osmosis, and ultrafiltration for solid organic matter;

- the dissolved solids that can be removed by reverse osmosis, ion exchange and electrodialysis;

- $\quad$ the possibility of integrating the proposed unit with existing installations; and

- the capital and operating costs.

The wastewater treatment methods for reuse at refineries can be classified as primary, secondary and tertiary. The primary methods are the simplest, including techniques such as oil/water separation and dissolved air flotation. These are considered conventional treatment techniques (see Section 2). Secondary treatment at refineries is used to remove a substantial part of the biodegradable organic matter. Tertiary treatment aims to remove ions (dissolved salts), to bring the quality up to the level required for reuse, mainly to feed cooling towers or boilers.

\subsection{Membranes for micro, ultra and nanofiltration}

Membrane processes are used to treat stable oil/water emulsions, especially water-soluble oily wastes, rather than oil floating in unstable emulsions, for which other methods are more suitable (Cheryan, 1998, as cited in Cheryan \& Rajagopalan, 1998). Membranes are effective in removing oil droplets with micrometric size, usually smaller than $10 \mu \mathrm{m}$, and when the oil concentration is very low (Chakrabarty et al., 2008). These cases cannot be resolved by conventional techniques such as gravity separation, addition of chemical agents, thermal demulsification and biological treatment. The porous membrane matrix promotes coalescence of the micrometric and sub-micrometric oil droplets, which then can be easily removed by gravity (Hlavacek, 1995).

Membrane processes have several advantages, among them lower capital cost, no need to add chemicals and no subsequent generation of oily sludge (Ohya et al., 1998); operational simplicity, lower energy costs than for thermal treatment (Cheryan \& Rajagopalan, 1998) and the capacity to produce a permeate with acceptable quality for discharge (Chakrabarty et al., 2008).

A membrane is a barrier that serves to separate two phases by selectively restricting the passage of chemical agents. A membrane can be homogeneous or heterogeneous, with a symmetric or asymmetric structure, and solid or liquid. It can selectively conduct a positive or negative charge or be neutral or bipolar. The transport through the membrane can be by convection or diffusion of individual molecules, by induction by an electrical field or by pressure or temperature gradient. The membrane's thickness can range from tens of microns to a few hundreds of micrometers (Ravanchi et al., 2009). 
The pores of the membrane act as a physical barrier to impurities while permitting the passage of water molecules. A driving force must be applied to promote transport of the solution through the membrane. The main driving forces are pressure difference, concentration (or activity) difference - including difference in chemical potential $(\mu)$ - or difference in electrical potential between the two sides of the membrane (Ravanchi et al., 2009).

The permeate flux (Jp) and the selectivity of the membrane to a determined component of the feed solution are important properties for operation of membrane systems (Habert et al., 2006). The permeate flux in processes that use pressure difference as the driving force (microfiltration, ultrafiltration, nanofiltration and reverse osmosis) is given by Equation (8). The membrane's selective capacity can be calculated by the retention coefficient (R), defined as the fraction of the solution retained (retentate) by the membrane for a given feed concentration (Equation (9)):

$$
\mathrm{J}_{\mathrm{P}}=\mathrm{L}_{\mathrm{P}}(\Delta \mathrm{P}-\Delta \pi),
$$

where $\mathrm{L}_{\mathrm{P}}$ is the hydraulic permeability (in $\mathrm{L} / \mathrm{m}^{2} \mathrm{~h}$ bar); $\Delta \mathrm{P}$ is the pressure difference (in bar); and $\Delta \pi$ is the osmotic pressure difference (in bar). $J_{P}$ is therefore given in $L / m^{2} h$. In turn, the retention coefficient is given by the following formula:

$$
\mathrm{R}(\%)=[(\mathrm{Cf}-\mathrm{Cp}) / \mathrm{Ca}] \times 100,
$$

where $\mathrm{Cf}$ is the feed solute concentration (ppm) and $\mathrm{Cp}$ is the solute concentration of the permeate (ppm).

Figure 2 presents the range of pore diameters and retention efficiencies of micro, ultra and nanofiltration membranes and of the reverse osmosis process (Perry \& Green, 2007).

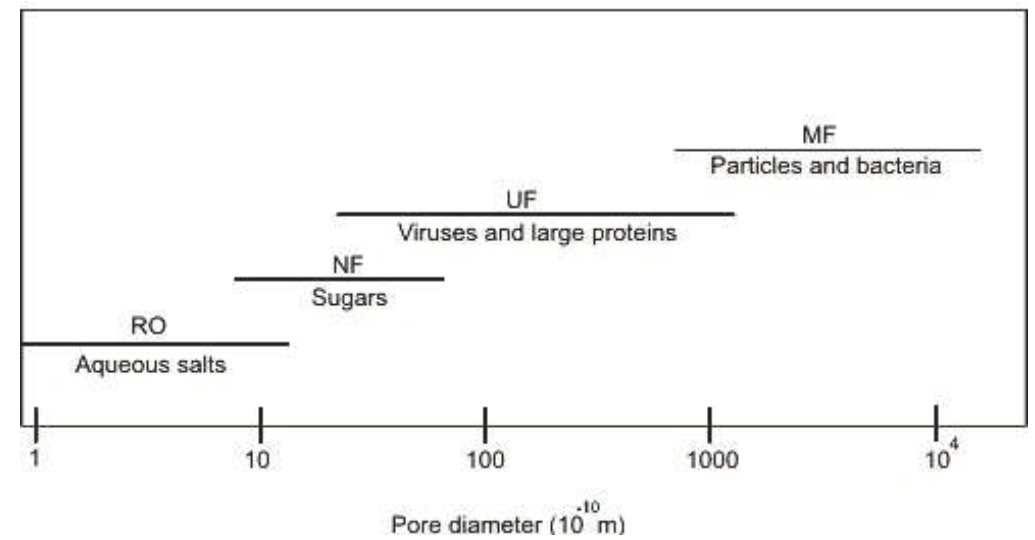

Note: RO - Reverse osmosis; NF - Nanofiltration; UF - Ultrafiltration; MF - Microfiltration.

Fig. 2. Range of pore diameters and removal efficiencies of micro, ultra and nanofiltration membranes and the reverse osmosis process (Perry \& Green, 2007).

\subsubsection{Microfiltration}

Microfiltration and ultrafiltration membranes are used after conventional treatment techniques and as pretreatment just before reverse osmosis, to prolong the useful life of the 
$\mathrm{RO}$ membrane and reduce incrustation (fouling) and operational costs of this process. They can also be used as part of a membrane bioreactor, to retain biomass, as will be discussed shortly. Microfiltration membranes are operated at a pressure of under 2.0 bar (Wagner, 2001).

Fouling is one of the main problems reducing the efficiency of membrane filters. It is caused by various factors, such as clogging of the pores, adsorption of solute by the membrane and formation of a gel on the membrane surface, among others. Fouling causes a gradual decline in the permeate flux when all the other parameters are constant (pressure, flow, temperature and feed concentration). Fouling can be either reversible or irreversible. The distinction is a consequence of the characteristics of the deposit formed on the membrane surface (temporary or permanent) and the possibilities of restoring the initial flux by backwashing or chemical cleaning. It also raises operating costs because of the higher pressure required to maintain the retention rate and the need to clean the membrane or to replace it in cases of irreversible fouling (Teodosiu et al., 1999).

\subsubsection{Ultrafiltration}

Ultrafiltration membranes are operated at a pressure range of 1.0 to 10.0 bar (Wagner, 2001). Teodosiu et al. (1999) studied the use of ultrafiltration (dual filtration with membranes made of polyethersulphone and polyvinylpirollidone) as pretreatment for reverse osmosis, for the purpose of recycling secondary refinery wastewater to feed cooling towers. An average efficiency of $98 \%$ was obtained for turbidity, meaning almost complete removal of suspended solids and colloids, along with efficiency of 30\% for COD in the tests.

In a system with ultrafiltration followed by reverse osmosis, the ultrafiltration can remove the suspended and colloidal material, bacteria, viruses and organic compounds, while the reverse osmosis removes dissolved salts, as will be discussed shortly. The quality requirements for cooling water are related to the limits established for substances that can cause scaling, corrosion, fouling and growth of microorganisms, all of which reduce the performance of cooling towers. Scaling is caused by the presence of carbonates and calcium and magnesium sulfates, which precipitate as scales in heat exchangers. Corrosion is related to the presence of large quantities of dissolved solids, including chloride and ammonia. Microorganisms grow because of the presence of high concentrations of nutrients or organic substances. And fouling occurs mainly due to the presence of high levels of suspended solids, although organic fouling via adsorption of dissolved organic compounds is also a problem (Teodosiu et al., 1999).

Chakrabarty et al. (2008) used modified polysulfone membranes with the objective of attaining higher porosity and hydrophobicity through the use of additives such as polyvinylpirollidone and polyethylene glycol to remove oil from wastewater. The experiments were conducted in 12 different membranes in a semi-batch filtration cell made of Teflon. The authors evaluated the influence of feed properties such as initial oil concentration and $\mathrm{pH}$ of the solution on membrane performance. They concluded that these characteristics significantly affect the permeate flux and oil separation. With increasing concentration the flux diminished and the retention increased due to the formation of an oil layer on the membrane surface, leading to an increase in total resistance. With relation to $\mathrm{pH}$, increased acidity or alkalinity of the feed solution caused greater oil retention for the four membranes selected in this analysis by the authors. The permeate flux varied according to the chemical composition of the membrane studied, and was highest under normal $\mathrm{pH}$ 
condition (of 6.12) in some cases, and at slightly alkaline $\mathrm{pH}$ (8.00) and slightly acid (5.00) conditions in other cases.

\subsubsection{Nanofiltration}

Nanofiltration membranes are operated at a pressure varying from 5 to 35 bar (Wagner, 2001). Nanofiltration membranes are generally used to separate multivalent ions and organic compounds with relatively low molecular weights $(250-1000 \mathrm{~g} / \mathrm{mol})$ from water. The treatment removes between 60 and $80 \%$ of the water hardness, over $90 \%$ of the color and all the turbidity (Bessarabov \& Twardowski 2002).

In aqueous solutions, the nanofiltration membranes become charged, permitting the separation of ionic species. It is believed that steric hindrance is the dominant retention mechanism in these membranes for colloids and large molecules, while physico-chemical interactions between the solute and membrane are more important for ions and organic materials with lower molecular weights. Figure 3 shows a hypothetical polymeric nanofiltration membrane with carboxyl groups linked at the membrane surface, which are produced in contact with an aqueous solution of an electrolyte. The presence of the carboxyl groups dissociated at the membrane surface (R-COO-) causes the occurrence of membrane charging (Bessarabov \& Twardowski, 2002).

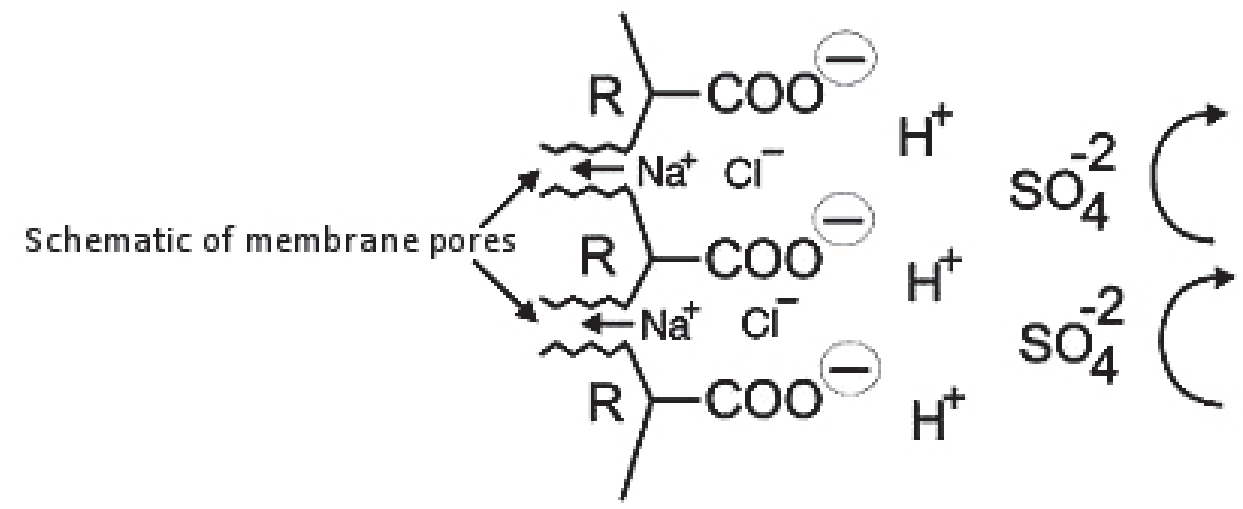

Fig. 3. Hypothetical polymeric nanofiltration membrane containing carboxyl groups. The presence of these groups dissociated at the membrane surface (R-COO-) causes membrane charging. This charge repels large $\mathrm{SO}_{4}{ }^{2-}$ ions and permits the passage of smaller $\mathrm{Cl}^{-}$ions through the membrane (Bessarabov \& Twardowski, 2002).

\subsection{Membrane bioreactors (MBR)}

Membrane bioreactors (MBR) remove a large amount of biodegradable material (measured as BOD and COD) from oil refinery wastewater.

MBR systems consist of a combination of the activated sludge biological process (see Section 2) with the membrane separation process. The reaction occurs like it does in the activated sludge process, with the added advantage of being able to operate without the need for clarification or steps like sand filtration (Melin et al., 2006). These systems use micro or ultrafiltration to separate the effluent from the activated sludge. The two main MBR configurations involve submerged or external separation membranes, as depicted in Figure 4. 
(a)

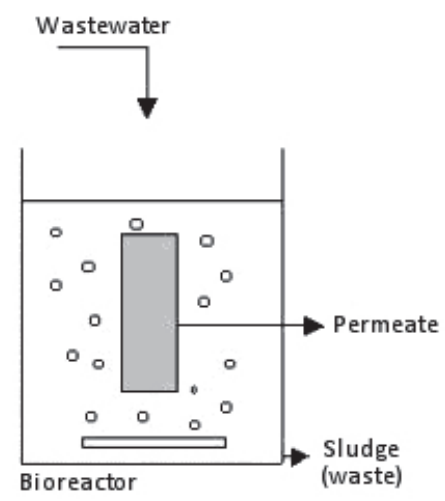

(b)

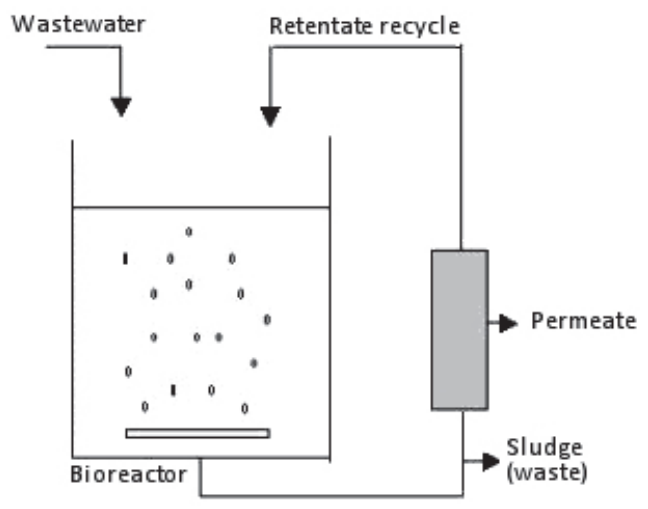

Fig. 4. Configuration of MBR systems. (a) Submerged MBR. (b) Lateral flow MBR (Melin et al., 2006).

The first option is more often applied to treat municipal wastewater (Melin et al., 2006), and can use both hollow fiber membranes (horizontal or vertical) and flat plate membranes (vertical). In side flow MBR systems, tubular membranes (horizontal or vertical) are placed outside the bioreactor and are fed by it. This system operates by cross-flow. Both systems are aerated at the lower part of the bioreactor, and the permeate is removed by suction (Oever, 2005).

As in regular membrane processes, fouling is a problem of membrane bioreactors, by hindering the permeate flux during filtration. This problem is influenced by the characteristics of the biomass, the operating conditions and characteristics of the membrane (Chang et al., 2002). The cost of periodically replacing the membrane because of aging and fouling raises the operating costs and reduces the competitiveness of the MBR technology (Buetehorn et al., 2008). Fouling is also influenced by the hydrodynamic conditions, type of membrane and configuration of the unit, as well as by the presence of compounds with high molecular weight, which can be produced by microbial metabolism or introduced by the sludge growth process (Melin et al., 2006).

Viero et al. (2008) evaluated the treatment of oil refinery wastewater using a submerged membrane bioreactor (SMBR), operating at a constant permeate flux. During the operation, high organic loading rates were applied to the unit by feeding mixtures of the effluent stream with another effluent having high phenolic strength, also generated by oil refineries. The influence of the loading rate on the filtration was assessed, including the effects on the production of soluble microbial products (polysaccharides and proteins) and the retention of these compounds by the membrane. The membrane played a key role in the process, since it improved the COD and TOC (total organic carbon) removal efficiencies by 17 and $20 \%$, respectively, in comparison with the results obtained with biomass alone. The authors observed that good efficiencies in removing organic matter, indicated by the COD and TOC results, were achieved considering the complexity of the wastewater stream processed. Additionally, the tested system was highly effective in removing phenols. 
Scholz \& Fuchsm (2000) reported tests of a MBR with high activated sludge concentration (above $48 \mathrm{~g} / \mathrm{L}$ ) and showed that oily wastewater also containing surfactants was biodegraded with high efficiency. During the different loading stages, a removal rate of $99.99 \%$ was attained for fuel oil as well as for lubricating oil, at a hydraulic retention time of 13.3 hours. The maximum biodegradation of the fuel oil was $0.82 \mathrm{~g}$ of hydrocarbons degraded per day. The average removal of COD and TOC during the experiments was $94-96 \%$ for fuel oil and $98 \%$ for lubricating oil, respectively. Because of the high efficiency in removing oily pollutants and complete retention of suspended solids by the ultrafiltration system, the authors stated the MBR system has good potential for industrial applications aiming to recycle effluents. The MBR removed $93-98 \%$ of the COD and $95-98 \%$ of TOC in a hydraulic retention time of 7-14 $\mathrm{h}$ and oil loading rates of 3-5 g/L/day (Scholz \& Fuchsm, 2000).

\subsection{Reverse osmosis}

Along with the reverse electrodialysis process, described next, reverse osmosis is used to remove ions (dissolved salts) from oil refinery wastewater, as part of the tertiary treatment cycle.

Reverse osmosis is by far the most common membrane process used for desalination. It can reject nearly all the colloidal or dissolved material in an aqueous solution, producing concentrated salty water and a permeate of virtually pure fresh water. Reverse osmosis is based on the property of certain polymers called semi-permeability. While semi-permeable membranes are highly permeable to water, they have low permeability to dissolved substances. When a pressure difference is applied across the membrane, the water molecules contained in the feed stream are forced to permeate through the membrane. This pressure must be high enough to overcome the osmotic pressure working against the feed (Fritzmann et al., 2007). This pressure is generally in the range of 15 to 150 bar (Wagner, 2001).

The osmosis process occurs when a semi-permeable membrane (permeable to water but not to the solute) separates the feed liquid into two aqueous solutions with different concentrations. At equal temperature and pressure on both sides of the membrane, the water will diffuse (permeate) through the membrane, resulting in an overall flow of the diluted solution to the more concentrated one until the concentrations on both sides of the membrane are equal. If the pressure differential $(\Delta \mathrm{p})$ is greater than the osmotic pressure $(\Delta \pi)$, the flow is reversed and the water flows from the concentrated to the diluted side. This process is called reverse osmosis. In water desalination, the feed side is operated under high pressure and the concentration of the solute on the permeate side (diluted) is negligible when compared to the feed concentration. In this case permeate flux occurs because the $\Delta p$ exceeds the $\Delta \pi$ of the feed solution (Fritzmann et al., 2007).

According to Nazarov et al. (1979), reverse osmosis can be employed to desalt waste streams from crude oil electric desalting units, where the salt content of these streams is very high (above 5,000 mg/L, including 75-85\% sodium chloride, 4-5\% magnesium chloride and 10$15 \%$ calcium chloride). They also mentioned the following aspects as advantages of reverse osmosis: the components (salts and water) are separated at ambient temperature without any phase conversion of the water (heating or cooling); the osmotic module is simple to design and operate; and the process can be fully automated. As disadvantages, they mentioned the difficulty of manufacturing reverse osmosis membranes, the low capacity of these membranes and the need to pre-treat the effluent to remove solid and emulsified contaminants or dissolved organic and inorganic substances.

In reverse osmosis, a dynamic layer of water and solutes is formed on the membrane surface. Only molecules of a strictly determined size will penetrate through this layer and 
through the membrane. Larger molecules do not pass through the membrane and are removed from the membrane surface under the influence of repulsive forces and longitudinal displacement of the liquid. Therefore, two streams are moving at the same time, a flow of liquid (water) and substances with low molecular weights through the layer of the membrane due to the difference in concentrations of these substances on either side of the membrane, and a flow of liquid and substances with high molecular weights from the surface of the membrane to within the solution, with subsequent carry-off (by purging) from the separation zone (Nazarov et al., 1979).

\subsection{Reverse electrodialysis}

The reverse electrodialysis process is also used to remove ions (dissolved salts) from oil refinery wastewater.

Electrodialysis can be used to concentrate or remove charged species in aqueous solutions. The process is based on the movement of charged species in an electrical field. Dissolved anions, such as $\mathrm{Cl}^{-}$and $\mathrm{NO}^{3-}$, move towards the anode while cations, such as $\mathrm{K}^{+}$and $\mathrm{Na}^{+}$, are attracted by the cathode. The movement of the ions is controlled by ion-selective membranes placed between the anode and cathode. Anion-exchange membranes (AEMs) are permeable to anions but not to cations, which are thus retained. Cation-exchange membranes (CEMs) work analogously but in the opposite way. The electrolysis device is divided into various cells by an alternating sequence of AEMs and CEMs. In this way, the concentration of ionic species is reduced in the diluted compartments and increased in the concentrate compartments. The basic unit of a device consists of a diluted compartment and a concentrate compartment in tandem (Fritzmann et al., 2007).

Figure 5 shows a diagram of the reverse electrodialysis process. The electrodes' polarity is

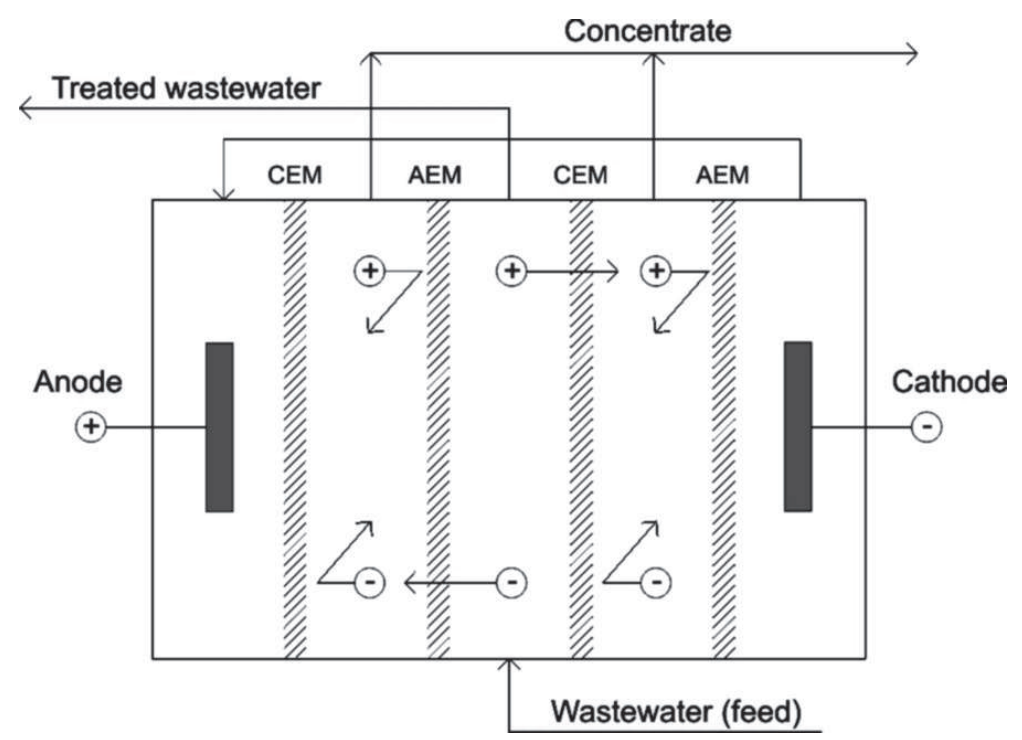

Note: CEM - Cation Exchange Membrane; AEM - Anion Exchange Membrane.

Fig. 5. The principle of reverse electrodialysis. 
periodically reversed, so that the direction of the ion movement is also reversed. Therefore, the concentrate streams become diluted streams and vice versa. The periodic switching of polarity works as a self-cleaning mechanism, reducing the surface fouling of the ionexchange membrane. Reverse electrodialysis systems are physically and chemically more durable than reverse osmosis systems and can support effluent flows with higher loads of organic matter, colloid particles and microorganisms than can reverse osmosis systems (Chao \& Liang, 2008).

\section{5 lon exchange}

Ion exchange processes occur with the substitution of the undesirable ions of a liquid (such as wastewater) with ions like $\mathrm{H}^{+}$and $\mathrm{OH}^{-}$from a solid material in which the ions are sufficiently mobile, usually a synthetic resin. Eventually the resin becomes exhausted and needs to be regenerated by contact with a small quantity of a solution with a high content of the desired ion. Resins can be tailored to have selective affinities for particular types of ions, such as mercury, boron, ferrous ions or copper in the presence of iron (Couper et al., 2010). An important property of these ion-exchange resins is their capacity to retain ions in their structure.

There are specific resins for each ion species: cationic, with the capacity to retain cations, and anionic, specific for retention of anions. Within these two groups of resins there is a further subdivision, summarized below. Each of these is suitable to remove specific ions and has particularities in its regeneration processes (Mierzwa \& Hespanhol, 2005).

- Strongly acidic cation-exchange resin: This type of resin has a chemical structure formed by styrene and divinylbenzene. Its functional groups are sulfonic acid radicals $\left(\mathrm{R}_{-} \mathrm{SO}_{3}{ }^{-}\right.$ $\mathrm{H}^{+}$). It can operate in a broad $\mathrm{pH}$ range and can be conditioned to operate in a sodium or hydrogen cycle, depending on the application: water softening or demineralization.

- Weakly acidic cation-exchange resin: Its functional groups are carboxylated (R-COOH), which are not ionized at low $\mathrm{pH}$ values. Therefore, this type of resin operates at $\mathrm{pH}$ values varying from neutral to alkaline. These resins are used to treat industrial water with high hardness, exclusively for calcium bicarbonate and carbonate.

- Strongly basis anion-exchange resin: Its functional group is quaternary amine (R$\left.\mathrm{N}\left(\mathrm{CN}_{3}\right)_{3}{ }^{+}\right)$. There are two sub-groups: Type I and Type II. The difference between these is basicity. Type I resins have a stronger basicity than Type II resins, and for this reason produce better output water, with less anion leakage principally of silica.

- Weakly basic anion-exchange resin: This type of resin is employed in water treatment systems designed mainly to remove anions from strong acids, among them chloride, sulfate and nitrate, because this type of resin is not able to remove weakly ionizable anions, among them bicarbonate and silica.

Except in very small-scale applications, ion exchangers are used in cyclical operations, involving sorption and desorption steps. A typical ion-exchange cycle used in water treatment applications involves: (a) backwashing: to remove accumulated solids and to fluidize the exchanger bed; (b) regeneration: a regenerant passes slowly through the exchanger to restore its original ionic form; (c) rinsing: water passes through the exchanger to remove the resin regenerant (in the case of porous exchangers, from the resin's pores); and (d) loading: the solution to be treated passes through the exchanger until the leakage starts to occur. Water softening occurs in this way, with a cation-exchange column containing sodium. At the low ionic strength used in the loading step, calcium and magnesium are strongly preferred over sodium, permitting nearly all of it to be removed. 
Since the selectivity for divalent cations diminishes sharply with ionic concentration, the regeneration is performed effectively with a concentrated sodium chloride solution. Removal of sulfates from boiler feed water is carried out by similar means with anion exchangers in chloride form (Perry \& Green, 2007).

Therefore, the ion-exchange process can treat effluents that contain dissolved ionic species, such as metals $\left(\mathrm{Al}^{3+}, \mathrm{Pb}^{2+}, \mathrm{Sr}^{2+}\right.$, etc.), inorganic anions $\left(\mathrm{F}-, \mathrm{NO}^{3-}, \mathrm{SO}_{4}{ }^{2-}, \mathrm{CN}-\right.$, etc. $)$ and organic acids (carboxylic, phenolic, etc.), among others. The advantages of using ion exchange are: (i) the generation of an outflow with higher quality than produced by other processes; (ii) the selective removal of undesired species; (iii) the fact that the process and equipment have been widely tested; (iv) the availability of automatic and manual systems in the market; and (v) the possibility of using them to treat small and large volumes of wastewater. In contrast, the disadvantages are: (i) the chemical products involved in the regeneration process; (ii) the relatively high concentration of contaminants and other compounds in the outflow; (iii) the possibility that organic substances, microorganisms, suspended particles and other substances will degrade or reduce the treatment capacity of the resins; and (iv) the possible impairment of the process by small variations in the feed stream characteristics (Mierzwa \& Hespanhol, 2005).

\subsection{Advanced oxidative processes}

Advanced oxidative processes are characterized by producing $\mathrm{OH}$ radicals, an extraordinarily reactive chemical species that attacks the majority of organic molecules. These processes can be used in pre- or post-treatment in a biological process, contributing to the degradation of toxic or refractory substances (Coelho, 2004). Table 1 summarizes the existing advanced oxidative processes (Andreozzi et al., 1999).

\begin{tabular}{|c|c|}
\hline \multicolumn{2}{|c|}{ Advanced oxidative processes } \\
\hline $\mathrm{H}_{2} \mathrm{O}_{2} / \mathrm{Fe}^{2+}$ & Fenton \\
\hline $\mathrm{H}_{2} \mathrm{O}_{2} / \mathrm{Fe}^{3+}$ & Fenton-like \\
\hline $\mathrm{H}_{2} \mathrm{O}_{2} / \mathrm{Fe}^{2+}\left(\mathrm{Fe}^{3+}\right) / \mathrm{UV}$ & Photo / Fenton \\
\hline $\mathrm{H}_{2} \mathrm{O}_{2} / \mathrm{Fe}^{3+}-\mathrm{Oxalate}$ & Photo / Fenton -like \\
\hline $\mathrm{Mn}^{2+} / \mathrm{Oxalic}^{3}$ cid / Ozone & Photocatalysis \\
\hline $\mathrm{TiO}_{2} / \mathrm{UV} / \mathrm{O}_{2}$ & Peroxidation \\
\hline $\mathrm{O}_{3} / \mathrm{H}_{2} \mathrm{O}_{2}$ & Oxidation by $\mathrm{O}_{3} / \mathrm{UV}$ \\
\hline $\mathrm{O}_{3} / \mathrm{UV}$ & Oxidation by $\mathrm{H}_{2} \mathrm{O}_{2} / \mathrm{UV}$ \\
\hline $\mathrm{H}_{2} \mathrm{O}_{2} / \mathrm{UV}$ &
\end{tabular}

Table 1. Advanced oxidative processes (Andreozzi et al., 1999).

Some of the processes cited above are described in more detail below (Castro, 2004). The Fenton, photo-Fenton, ozone and $\mathrm{H}_{2} \mathrm{O}_{2} / \mathrm{UV}$ processes act in the following form (Reactions (10), (11), (12), (13), (14), respectively - Reactions (12) and (13) refer to the process with ozone):

$$
\begin{gathered}
\mathrm{H}_{2} \mathrm{O}_{2}+\mathrm{Fe}^{2+} \rightarrow \mathrm{Fe}^{3+}+\mathrm{OH}^{-}+\mathrm{OH} \\
\mathrm{Fe}^{3+}+\mathrm{H}_{2} \mathrm{O}+\mathrm{hv} \rightarrow \mathrm{Fe}^{2+}+\mathrm{OH}+\mathrm{H}^{+}
\end{gathered}
$$




$$
\begin{gathered}
\mathrm{O}_{3}+\mathrm{OH}^{-} \rightarrow \mathrm{O}_{2}+\mathrm{O}_{2} \\
\mathrm{O}_{3}+\mathrm{H}_{2} \mathrm{O} \rightarrow 2 \mathrm{OH} \cdot+\mathrm{O}_{2} \\
\mathrm{H}_{2} \mathrm{O}_{2} \rightarrow(\mathrm{hv}) 2 \mathrm{OH}
\end{gathered}
$$

Equations (15) to (19) represent the reactions between organic substances and the hydroxyl radical (Castro, 2004):

- Addition

$$
\mathrm{Ar}-\mathrm{H}+\mathrm{OH} \rightarrow \mathrm{Ar}-\mathrm{OH}+\mathrm{H}
$$

- Abstraction of hydrogen:

$$
\mathrm{R}-\mathrm{H}+\mathrm{OH} \rightarrow \mathrm{H}_{2} \mathrm{O}+\mathrm{R}
$$

- Electron transfer:

$$
\mathrm{R} \cdot+\mathrm{O}_{2} \rightarrow \mathrm{ROO} \cdot
$$

- Termination (interaction of radicals):

$$
\begin{gathered}
\mathrm{R} \cdot+\mathrm{R} \cdot \rightarrow \mathrm{R}-\mathrm{R} \\
\mathrm{OH}+\mathrm{OH} \rightarrow \mathrm{H}_{2} \mathrm{O}_{2}
\end{gathered}
$$

Coelho et al. (2006) investigated the performances of various advanced oxidative processes to remove organic pollutants from sourwater from oil refineries. The preliminary experiments were conducted using the $\mathrm{H}_{2} \mathrm{O}_{2}, \mathrm{H}_{2} \mathrm{O}_{2} / \mathrm{UV}$, UV, photocatalysis, ozonization, Fenton and photo-Fenton processes. Only the Fenton and photo-Fenton processes produced satisfactory results, considered to be reduction of the dissolved organic carbon (DOC) of the sourwater by $35 \%$. For this reason, these two techniques were analyzed in more detail. The authors observed that the photo-Fenton process was very rapid, taking only a few minutes to attain a final DOC removal of $13-27 \%$ due to the formation of iron complexes. Radiation for an additional period of 60 minutes was found to increase the DOC removal to above $87 \%$. DOC removal rates above $75 \%$ were achieved when the reaction system was operated at hydraulic retention times longer than $85 \mathrm{~min}$. In the batch experiments, the maximum DOC removal was $87 \%$, using 4 and $0.4 \mathrm{~g} / \mathrm{L}$ of ferrous sulfate and hydrogen peroxide, respectively. The Fenton reaction was also very fast, but lower DOC removal rates were attained, depending on the ferrous sulfate concentration used. The photo-Fenton process, meanwhile, was able to improve the DOC removal in a short interval (50 min), leading to high overall performance levels. The highest DOC removal (94\%) was achieved with continuous operation of the combined processes (Fenton and photo-Fenton), when the system was operating with a hydraulic retention time of $1200 \mathrm{~min}$. However, appreciable DOC removal rates (greater than $75 \%$ ) were also obtained with hydraulic retention times in the range of 60 to $120 \mathrm{~min}$. (Coelho et al., 2006).

\section{Assessment of the costs and applications in Brazil}

Wagner (2001) indicated the costs of membrane processes. According to him, the cost if installing a plant with spiral filters is between US\$ 300 and 500 per $\mathrm{m}^{2}$ of membrane area, 
while tubular systems are sold for more than US\$1,000 per $\mathrm{m}^{2}$. The price of a flat plate system ranges from US\$ 200 to 300 per $\mathrm{m}^{2}$. The cost of units with a fiber membrane configuration is US\$ 1,700 per $\mathrm{m}^{2}$, while ceramic systems are the most expensive, at US\$ 10,000 per $\mathrm{m}^{2}$. These costs refer to complete systems, that is, membranes, internal pipes, pumps and control equipment.

Spiral membranes were originally made for water desalination, but their compact configuration and low cost make them attractive for industrial applications. Tubular systems are simple and have the advantage of tolerating suspended solids and fibers. Flat plate systems are robust and compact. Fiber membrane systems are mechanically more fragile and thus are used only for determined ultrafiltration applications and oil emulsions. Finally, ceramic systems can be very effective for microfiltration (Wagner, 2001).

Depending on the capacity, a membrane filtration system can cost around US\$1300$5300 / \mathrm{m}^{3} /$ day, while the operating costs are between US\$ $0.79-3.96 / \mathrm{m}^{3}$ of treated wastewater (micro and ultrafiltration technologies) (Cheryan \& Rajagopalan, 1998).

Another source (CostWater, 2010) mentions the costs of membrane technology for microfiltration to remove particulate matter according to treatment capacity. According to this source, the costs are considerably lower than those mentioned above, ranging from US\$ $400 / \mathrm{m}^{3} /$ day for treatment capacity of $38,000 \mathrm{~m}^{3} /$ day to around US $\$ 600 / \mathrm{m}^{3} /$ day for a capacity of $3,800 \mathrm{~m}^{3} /$ day.

Membranes are a promising technology for treatment of refinery wastewater for reuse. They are generally used for pretreatment before reverse osmosis or reverse electrodialysis (micro and ultrafiltration technologies). Figure 6 shows a diagram of an advanced wastewater treatment system for reuse at oil refineries, considering ultra and microfiltration membranes and reverse osmosis or reverse electrodialysis as tertiary treatment.

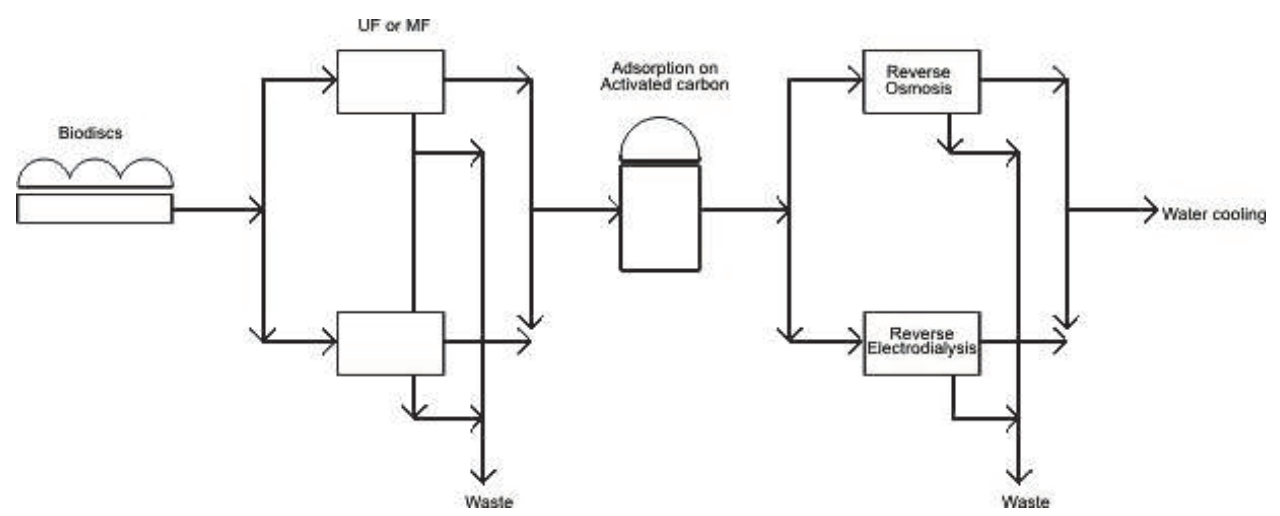

Fig. 6. Diagram of a wastewater treatment process for reuse at oil refineries (adapted from CENPES, 2004).

For MBR systems, the costs of membrane bioreactors fell from US\$ 400/ $\mathrm{m}^{2}$ to around US\$ $50 / \mathrm{m}^{2}$ in the 1990s. Figures from the EPA show an operating cost of US\$ $0.47 / \mathrm{m}^{3}$ of treated wastewater, including electricity, membrane exchange and chemical inputs but not amortization of the initial outlay. Other estimates show the operating cost of MBR unit with capacity of 3,785 $\mathrm{m}^{3} /$ day is around US\$ $0.11-0.15$ per $\mathrm{m}^{3}$ of treated effluent. These estimates are much lower than that of the EPA. The operating cost per volume treated appears not to very much with the system's capacity (CostWater, 2010). 
Oever (2005) mentioned the AirLift MBR system, which uses air to create turbulence and keep the membrane surface clean, with specific energy consumption of approximately 0.4 to $0.7 \mathrm{kWh} / \mathrm{m}^{3}$. This consumption would mean a cost of $\mathrm{R} \$ 0.0965$ to $0.1689 / \mathrm{m}^{3}$ at the industrial electricity tariff in the Southeast region of Brazil (where more than half of the country's refining capacity is located), at the rate in effect in December 2009 (R\$ 241.25/MWh) (ANEEL 2010). (US\$ $1.00=\mathrm{R} \$ 1.75228$ on December 31, 2009.)

Figure 7 shows a diagram of an advanced refinery wastewater treatment system considering membrane bioreactors for secondary treatment and reverse osmosis or reverse electrodialysis as tertiary treatment (Torres at al., 2008).

As can be observed, the effluent system passes through the primary treatment processes and then the oil polishing process, which can be by sand filtration, as shown in Figure 7, or nutshell filtration (for protection of the membrane) (CENPES, 2005). Nutshells are highly effective in absorbing free oil and suspended solids, due to their characteristic of promoting the coalescence of oil droplets. Activated carbon filters help remove refractory organic compounds from the biological process, allowing the treated effluent to be reused as industrial water.

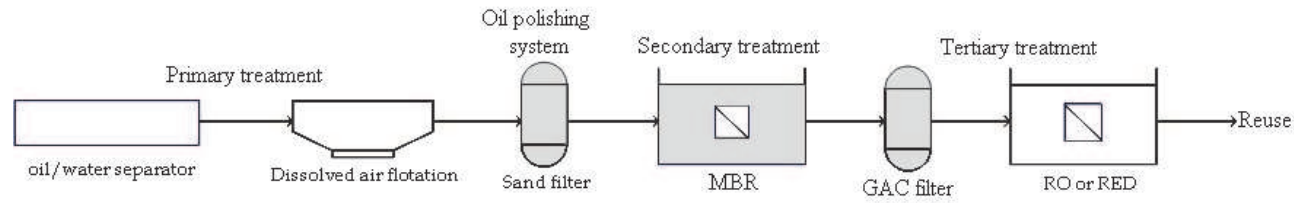

Note: GAC - Granulated Activated Carbon; RED - Reverse electrodialysis.

Fig. 7. Advanced oil refinery wastewater treatment (adapted from Torres et al., 2008).

Membrane bioreactors for wastewater reuse have been or are being installed at various existing Petrobras refineries or will be at new refineries. Table 2 presents these projects (Santiago, 2009).

\begin{tabular}{|l|l|l|l|}
\hline \multicolumn{1}{|c|}{ Refinery } & \multicolumn{1}{c|}{ Description } & \multicolumn{1}{c|}{ Capacity $\left.\mathbf{~} \mathbf{m}^{3} / \mathbf{h}\right)$} & \multicolumn{1}{c|}{ Start of Operation } \\
\hline REVAP & $\begin{array}{l}\text { New Industrial Waste } \\
\text { Treatment Station }\end{array}$ & 300 & 2009 \\
\hline CENPES* & $\begin{array}{l}\text { New Industrial Waste } \\
\text { Treatment Station }\end{array}$ & 65 & 2010 \\
\hline REPAR & $\begin{array}{l}\text { New Industrial Waste } \\
\text { Treatment Station }\end{array}$ & 400 & 2011 \\
\hline COMPERJ & New Refinery & 1100 & 2012 \\
\hline RENEST & New Refinery & 600 & - \\
\hline REGAP & $\begin{array}{l}\text { New Biological } \\
\text { Treatment Unit }\end{array}$ & 750 & - \\
\hline LUBNOR & $\begin{array}{l}\text { New Industrial Waste } \\
\text { Treatment Station }\end{array}$ & 66 & \\
\hline
\end{tabular}

Note: ${ }^{*}$ CENPES is a pilot project at the Petrobras Research Center.

Table 2. Membrane bioreactor units at refineries under construction (Santiago, 2009). 

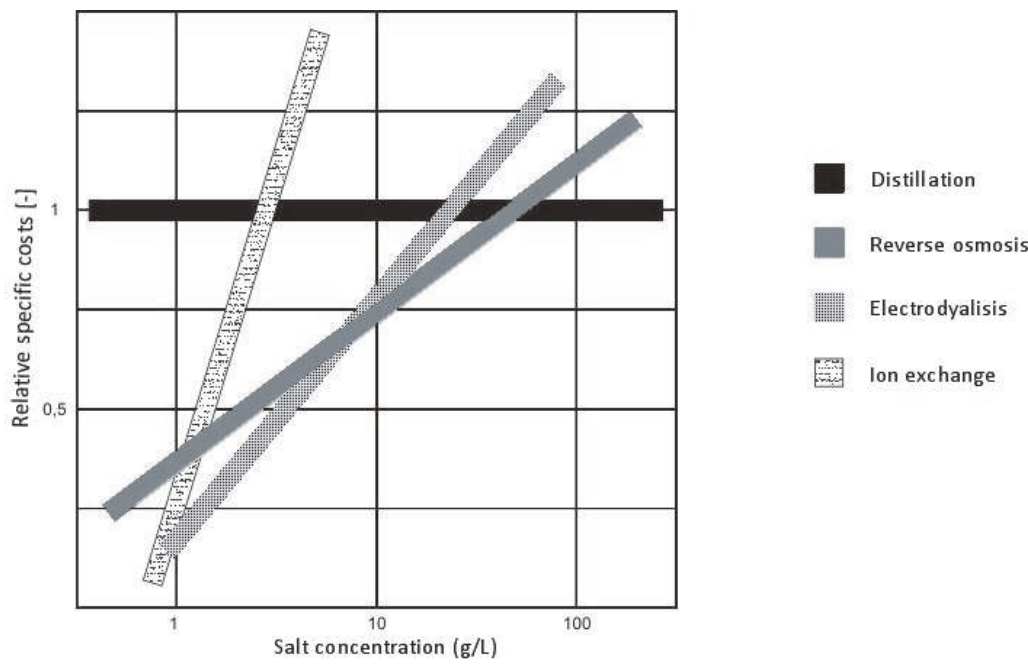

Fig. 8. Costs of wastewater treatment with ion exchange and competing technologies (Rautenbach \& Melin, 2003, as cited in Fritzmann et al., 2007).

The capital cost of the reverse osmosis technology in Brazil is from US\$1454 to $4483 / \mathrm{m}^{3} /$ day, while the operating cost ranges from US\$ 0.12 to $0.37 / \mathrm{m}^{3}$ (including amortization of the investment, operation and maintenance and membrane substitution) (OAS, 2010).

According to Fritzmann et al. (2007), electricity consumption of the reverse osmosis process is between 0.4 and $7 \mathrm{kWh} / \mathrm{m}^{3}$ of treated effluent. That consumption range would mean a cost of $\mathrm{R} \$ 0.0965$ to $1.6888 / \mathrm{m}^{3}$, considering the industrial electricity tariff in the Southeast region of Brazil in December 2009 (R\$ 241.25/MWh) (ANEEL, 2010).

In treatment of refinery wastewater for reuse, reverse osmosis is used as tertiary treatment to remove ions (such as chlorides), as already mentioned. The competing technology is reverse electrodialysis.

According to Fritzmann et al. (2007), electrodialysis consumes $1 \mathrm{kWh}$ of electricity per $\mathrm{m}^{3}$ of treated wastewater. At the average industrial energy rate in the Southeast region in December 2009 (R 241.25/MWh), this would cost R\$ 0.2413/ $\mathrm{m}^{3}$ (ANEEL, 2010).

Chao \& Liang (2008) also estimated the operating cost of a mini reverse electrodialysis plant. According to their calculations, the electricity consumption by electrodes and pumps is 0.85 $\mathrm{kWh} / \mathrm{m}^{3}$ of treated effluent, which works out to $\mathrm{R} \$ 0.205 / \mathrm{m}^{3}$ at the same industrial rate applied above (ANEEL, 2010). They estimated the total operating costs, including electricity and chemicals, at US\$ $0.146 / \mathrm{m}^{3}$.

The reverse electrodialysis process is promising for removal of ions (such as chlorides) from refinery wastewater, as mentioned. In a test program to analyze technologies to remove ions for reuse of wastewater (reverse osmosis and reverse electrodialysis) at pilot units at the REGAP refinery, reverse electrodialysis was the most promising. The advantage of this technology was its greater operational continuity. Both the reverse osmosis and reverse electrodialysis pilot plants were fed with effluent from the microfiltration unit, after filtration by activated charcoal. There was no fouling of the reverse electrodialysis 
membranes, while this was a serious problem with the reverse osmosis membranes, causing increased pressure and frequent need for chemical cleaning (CENPES, 2004).

With respect to the costs of the ion exchange process, Figure 8 presents these costs in comparison with those of competing technologies (Rautenbach \& Melin, 2003, as cited in Fritzmann et al., 2007).

It can be seen from the figure that for low salt concentrations, ion exchange is a competitive technology. This indicates that ion exchange can be used for the polishing step for reverse osmosis for treatment of wastewater for reuse at refineries in Brazil and the rest of the world.

Table 3 shows the operating costs of treatment to remove nitrophenols with advanced oxidative processes, for $90 \%$ reduction (initial concentration of $0.04 \mathrm{mM}$ ) (Goi \& Trapido, 2002).

\begin{tabular}{|c|c|c|c|c|c|c|}
\hline $\begin{array}{c}\text { Treatment } \\
\text { Process }\end{array}$ & Compound & $\begin{array}{c}{\left[\mathrm{H}_{2} \mathrm{O}_{2}\right] \mathrm{o}} \\
(\mathrm{mM})\end{array}$ & $\begin{array}{c}{\left[\mathrm{Fe}^{2+}\right] \mathrm{o}} \\
(\mathrm{mM})\end{array}$ & $\begin{array}{c}\text { Energy } \\
\text { required } \\
\left(\mathrm{kWh} / \mathrm{m}^{3}\right)\end{array}$ & $\begin{array}{c}\text { Energy } \\
\text { cost } \\
\left(\mathrm{US} \$ / \mathrm{m}^{3}\right)\end{array}$ & $\begin{array}{l}\text { Total cost } \\
\text { (US } \$ \mathrm{~m}^{3} \text { ) }\end{array}$ \\
\hline$U V$ & $\begin{array}{l}, 6-\mathrm{DN}-0- \\
\mathrm{CR} \\
2,6-\mathrm{DNP} \\
4-\mathrm{NP}\end{array}$ & $\begin{array}{l}0 \\
0\end{array}$ & $\begin{array}{l}0 \\
0 \\
0\end{array}$ & $\begin{array}{l}901 \\
658 \\
872\end{array}$ & $\begin{array}{l}63.10 \\
46.10 \\
61.10\end{array}$ & $\begin{array}{l}63.10 \\
46.10 \\
61.10\end{array}$ \\
\hline $\mathrm{UV} / \mathrm{H}_{2} \mathrm{O}_{2}$ & $\begin{array}{l}\text { 4,6-DN-0- } \\
\text { CR } \\
\text { 2,6-DNP } \\
4-\mathrm{NP}\end{array}$ & $\begin{array}{l}10 \\
10 \\
10\end{array}$ & $\begin{array}{l}0 \\
0 \\
0\end{array}$ & $\begin{array}{l}21.9 \\
16.3 \\
5.15\end{array}$ & $\begin{array}{l}1.53 \\
1.14 \\
0.36\end{array}$ & $\begin{array}{l}1.82 \\
1.43 \\
0.65\end{array}$ \\
\hline Fenton & $\begin{array}{l}4,6-\mathrm{DN}-0- \\
\mathrm{CR} \\
2,6-\mathrm{DNP} \\
4-\mathrm{NP}\end{array}$ & $\begin{array}{l}4 \\
4 \\
2\end{array}$ & $\begin{array}{l}0.4 \\
0.4 \\
0.1\end{array}$ & $\begin{array}{l}0 \\
0 \\
0\end{array}$ & $\begin{array}{l}0 \\
0 \\
0 \\
0\end{array}$ & $\begin{array}{l}0.13 \\
0.13 \\
0.06\end{array}$ \\
\hline $\begin{array}{l}\text { Photo- } \\
\text { Fenton }\end{array}$ & $\begin{array}{l}4,6-\mathrm{DN}-0- \\
\mathrm{CR} \\
2,6-\mathrm{DNP} \\
4-\mathrm{NP}\end{array}$ & $\begin{array}{l}4 \\
4 \\
4 \\
2\end{array}$ & $\begin{array}{l}0.4 \\
0.1 \\
0.1\end{array}$ & $\begin{array}{l}2.39 \\
\\
2.06 \\
2.00\end{array}$ & $\begin{array}{l}0.17 \\
0.14 \\
0.14\end{array}$ & $\begin{array}{l}0.30 \\
0.26 \\
0.20\end{array}$ \\
\hline
\end{tabular}

Note: DN - dinitro; CR - cresol; DNP - dinitrophenol; NP - nitrophenol.

Table 3. Operating cost for treatment to remove nitrophenols with advanced oxidative processes, for $90 \%$ reduction (initial concentration of $0.04 \mathrm{mM}$ ) (Goi \& Trapido, 2002).

Advanced oxidative processes can be used to treat sourwater from oil refineries containing low biodegradability compounds and toxic substances that prevent use of biological treatment (Coelho et al., 2006). Sourwater is an industrial effluent that should be segregated and treated by combined processes because of its complex chemical composition (see Table 4), containing emulsified oil, phenols, sulfides, mercaptants, ammonia, cyanide and other micro-pollutants.

Despite its complex composition, sourwater can be considered a candidate for industrial reuse when submitted to efficient treatment processes. It is produced when steam is injected in some refinery processing units to reduce the initial steam pressures of hydrocarbons, permitting operation at lower temperatures. After separation at the top of the tower, the sourwater can be 
fed into a rectification tower to remove ammonia and hydrogen sulfide. Besides being highly polluting, sourwater is very corrosive. The amount of sourwater generated by a refinery depends on various factors, including the process configuration and type and characteristics of the crude oil being processed. Typical production of sourwater at large refineries ranges from 0.2 to $0.5 \mathrm{~m}^{3}$ / tonne (metric ton) of crude oil (Coelho et al., 2006).

\begin{tabular}{|c|c|}
\hline Parameter & Range or average \\
\hline COD $(\mathrm{mg} / \mathrm{L})$ & $850-1020$ \\
\hline DOC $(\mathrm{mg} / \mathrm{L})$ & $300-440$ \\
\hline BOD $_{5}$ & 570 \\
\hline Phenol $(\mathrm{mg} / \mathrm{L})$ & $98-128$ \\
\hline Ammonia $(\mathrm{mg} / \mathrm{L})$ & $5.1-21.1$ \\
\hline TSS $(\mathrm{mg} / \mathrm{L})$ & n.d $^{\mathrm{a}}$ \\
\hline VSS $(\mathrm{mg} / \mathrm{L})$ & $\mathrm{n}^{\mathrm{a}} \mathrm{d}^{\mathrm{a}}$ \\
\hline $\mathrm{pH}$ & $8-8.2$ \\
\hline Turbidity $(\mathrm{NTU})$ & $22-52$ \\
\hline Sulfide $(\mathrm{mg} / \mathrm{L})$ & $15-23$ \\
\hline Toluene $(\mu \mathrm{g} / \mathrm{L})$ & 1.1 \\
\hline Ethylbenzene $(\mu \mathrm{g} / \mathrm{L})$ & 3.7 \\
\hline m,p-Xylene $(\mu \mathrm{g} / \mathrm{L})$ & 15.4 \\
\hline o-Xylene $(\mu \mathrm{g} / \mathrm{L})$ & 3.7 \\
\hline Oil and grease $(\mathrm{mg} / \mathrm{L})$ & 12.7 \\
\hline
\end{tabular}

Note: a - not detected; TSS - Total Suspended Solids; VSS - Volatile Suspended Solids.

Table 4. Average characteristics of sourwater (Coelho et al., 2006).

\section{Conclusion}

Brazil is currently expanding its refining capacity and faces problems of localized water shortage, both in semi-arid regions and intensely urbanized ones (such as the metropolitan areas of Rio de Janeiro and São Paulo), in the latter case because of high water demand. This chapter presented conventional wastewater treatment technologies and those aimed at improving the quality sufficiently for reuse. In the second case, the costs and perspectives for application in Brazil were presented.

The conventional wastewater treatment methods at oil refineries include gravity separation (mainly in API separators), dissolved air flotation, demulsification, coagulation, flocculation and biological treatment (aerated lagoons, activated sludge systems and biodiscs).

For treatment of refinery wastewater for reuse, the technologies include membranes (micro and ultrafiltration), membrane bioreactors (MBRs), reverse osmosis and reverse electrodialysis. These technologies work in series with conventional treatment techniques.

Some technologies, not yet applied in large scale for treating refinery effluents aiming at reuse, are promising and should be tested further. Among these are nanofiltration, which presents removal efficiency levels between those of ultrafiltration and reverse osmosis; ion exchange, which as shown in this chapter would be useful for the polishing step of reverse osmosis; and advanced oxidative processes, which are effective for treating sourwater. Despite the expensive investigations summarized here, further studies are necessary to 
assess the feasibility of these technologies for large-scale application to treat oil refinery wastewater for reuse.

\section{Acknowledgments}

We thank the National Research Council (CNPq) and the Rio de Janeiro State Research Foundation (FAPERJ) for funding.

\section{References}

Agência Nacional de Energia Elétrica - ANEEL. Retrieved on: August 26, 2010. Available from: <www.aneel.gov.br/arquivos/PDF/informacoes_gerenciais_novo.pdf>.

Al-Shamrani, A.A., James, A., Xiao, H. (2002) Destabilisation of oil-water emulsions and separation by dissolved air flotation. Water Research, Vol. 36, No. 6, (March 2002), pp. 1503-1512, ISSN 0043-1354.

Amorim, R.S. (2005). Abastecimento de água em uma refinaria de petróleo - Caso Replan. Master's dissertation in Management System, Universidade Federal Fluminense.

Andreozzi, R.; Caprio, V., Insula, A. Marotta, R. (1999). Advanced oxidation processes (AOP) for water purification and recovery. Catalysis Today, Vol. 53, No.1, (October 1999), pp. 51-59, ISSN 0920-5861.

Bessarabov, D.; Twardowski, Z. (2002). Industrial application of nanofiltration - new perspectives. Membrane Technology, (September 2002), pp. 6-9.

Braile, P.M. (1979). Manual de Tratamento de águas residuárias industriais, CIA Estadual Tecnol. Saneamento Ambiental, São Paulo.

Buetehorn, S.; Koh, C.N.; Wintgens, T. Volmering, D. Vossenkaul, K.; Melin, T. (2008). Investigating the impact of production conditions on membrane properties for MBR applications. Desalination, Vol .231, No. 1-3, (October, 2008), pp. 191-199, ISSN 0011-9164.

Castro, A.V.S. (2004). Processos Oxidativos Avançados para tratamento de águas ácidas de refinarias de petróleo, Master's dissertation in chemical engineering, Instituto Alberto Luiz Coimbra de Pós-graduação e Pesquisa de Engenharia (COPPE/UFRJ).

Cenpes. (2004). Efluentes hídricos: Resultados em P \& D. Avaliação de tecnologias visando ao reúso de efluentes, (June 2004), Cenpes, Rio de Janeiro.

Cenpes. (2005). Efluentes hídricos: Resultados em P \& D. Tratamentos avançados de efluentes hídricos - PROAMB 5. Unidade protótipo de biorreator a membrana, (December 2005), Cenpes, Rio de Janeiro.

Chao, Y; Liang T.M. A feasibility study of industrial wastewater recovery using electrodialysis reversal. (2008). Desalination, Vol. 221, No. 1-3, (March 2008), pp. 433-439, ISSN 0011-9164.

Chakrabarty, B.; Ghoshal, A.K.; Purkait, M.K. (2008). Ultrafiltration of stable oil-in-water emulsion by polysulfone membrane. Journal of Membrane Science, Vol. 325, No. 1, pp. 427-437, ISSN 0376-7388.

Chang, I.S., Le Clech, P., Jefferson, B., Judd, S. (2002). Membrane fouling in membrane bioreactors for wastewater treatment. Journal of Environmental Engineering, Vol. 128, No. 11, pp. 1018-1029, ISSN.0733-9372.

Cheryan, M., Rajagopalan, N. (1998). Membrane processing of oily streams. Wastewater treatment and waste reduction. Journal of Membrane Science, Vol. 151, No. 1, (December 1998), pp. 13-28, ISSN 0376-7388. 
Coelho, A.D. (2004). Tratamento de águas ácidas de refinaria de petróleo pelos processos Fenton e Foto-Fenton, Master's dissertation in chemical engineering, Instituto Alberto Luiz Coimbra de Pós-graduação e Pesquisa de Engenharia (COPPE/UFRJ).

Coelho, A.; Castro, A.V.; Dezotti, M.; Sant'Anna Jr., G.L. (2006). Treatment of petroleum refinery sourwater by advanced oxidation processes. Journal of Hazardous Materials, Vol. 137, No. 1, (September 2006), pp.178-184, ISSN 0304-3894.

CostWater.. Retrieved on: July 20, 2010. Available from: <http:/ /www.costwater.com>.

Couper J.R., Penney W.R., Fair J.R., Walas S.M. (2010). Chemical Process Equipment: Selection and Design, Elsevier, London.

Empresa de Pesquisa Energética - EPE. (2007). Plano Nacional de Energia 2030, EPE, Rio de Janeiro.

Environmental Protection Agency - EPA. (2008). BAT guidance note on best available techniques for oil and gas refineries, 1. edition, ISBN: 1-84095-291-1, USA.

Ferreira, E.F.T., Almeida, J.H.C., Santiago, V.M.J., Wachburger, R.L. (2000). Ampliação da Estação de Tratamento de Despejos Industriais (ETDI) da Refinaria Alberto Pasqualini (REFAP) da Petrobras, Proceedings of XXVII Congresso Interamericano de Engenharia Sanitária e Ambiental.

Fritzmann, C; Löwenberg, J.; Wintgens, T.; Melin, T. (2007). State-of-the-art of reverse osmosis desalination. Desalination, Vol. 216, No. 1-3, (October 2007), pp. 1-76, ISSN 0011-9164.

Goi, A.; Trapido, M. (2002). Hydrogen peroxide photolysis, Fenton reagent and photoFenton for the degradation of nitrofenols: a comparative study. Chemosphere, Vol. 46, No. 6, (February 2002), pp. 913-922, ISSN 0045-6535.

Habert, A.C., Borges, C.P., Nóbrega, R. (Eds.). (2006). Processos de separação por membranas, Série Escola Piloto em Engenharia Química (COPPE/UFRJ), Rio de Janeiro.

Perry, R.H.; Green, D.W. (Eds). (2007). Perry's Chemical Engineers' Handbook, McGraw Hill, New York.

Hami, M.L., Al-Hashimi, M.A., Al-Doori, M.M. Effect of activated carbon on BOD and COD removal in a dissolved air flotation unit treating refinery wastewater. (2007). Desalination, Vol. 216, No. 1-3, (October 2007), pp. 116-122, ISSN 0011-9164.

Hlavacek, M. (1995). Break-up of oil-in-water emulsions induced by permeation through a microfiltration membrane. Journal of Membrane Science, Vol. 102, No. 15, (June 1995), pp. 1-7, ISSN 0376-7388.

Jaworski, A.J. (2009). On-line measurement of separation dynamics in primary gas/oil/water separators: Challenges and technical solutions - a review. Petroleum Science and Engineering, Vol. 68, No. 1-2, (September 2009), pp. 47-59, ISSN 0920-4105.

Luz, A.B., Sampaio, J.A., Monte, M.B.M., Almeida, S.L.M. (Eds.). (2002). Tratamento de Minérios, Centro de tecnologia mineral - CETEM, 3. edition, Rio de Janeiro.

Matos, O.S. (2005). Avaliação do desempenho e caracterização de parâmetros em Lagoa seguida de Lagoa de sedimentação, Master's dissertation in civil engineering, Instituto Alberto Luiz Coimbra de Pós-graduação e Pesquisa de Engenharia (COPPE/UFRJ).

Matsumura, E.M., Mierzwa, J.C. (2008). Water conservation and reuse in poultry processing plant - A case study. Resources Conservation \& Recycling, Vol. 52, No. 6, (April 2008), pp. 835-842, ISSN 0921-3449.

Melin, T.; Jefferson, B.; Bixio, D.; Thoeye, C.; De Wilde, W.; De Koning, J.; Van der Graaf, J.; Wintgens, T. (2006). Membrane bioreactors technology for wastewater treatment and reuse. Desalination, Vol. 187, No. 1-3, (February 2006), pp. 271-282, ISSN 0011-9164.

Mierzwa, J.C. Hespanhol, I. (2005). Água na Indústria - Uso racional e reúso, Oficina de Textos, São Paulo. 
Nazarov, V.I., Asylova, K.G., Lukinskaya, N.G. (1979) Refinery wastewater desalting by means of reverse osmosis. Chemistry and Technology of Fuels and Oils, Vol. 15, No. 4, pp. 278281.

Oever, R.V. MBR focus: is submerged best? Filtration + Separation, (June 2005), pp. 24-27.

Ohya, H.; Kim, J.J.; Chinen, A.; Aihara, M.; Semenova, S.I.; Negishi, Y.; Mori, O.; Yasuda, M. (1998). Effects of pore size on separation mechanisms of microfiltration of oily water, sing porous glass tubular membrane. Journal of Membrane Science, v. 145, No. 1, (June 1998), pp. 1-14, ISSN 0376-7388.

Organization of American States - OAS. Desalination by Reverse Osmosis. Available at: http://www.oas.org/DSD/publications/Unit/oea59e/ch20.htm. Retrieved on: August 31, 2010.

Piras, P.R.F. (1993). Tratamento biológico de efluentes de refinaria de petróleo em lagoas aeradas em série, Master's dissertation in chemical engineering, Instituto Alberto Luiz Alberto Coimbra de Pós-graduação e Pesquisa de Engenharia (COPPE/UFRJ).

Ravanchi, M.T.; Kaghazchi, T.; Kargari, A. (2009). Application of membrane separation processes in petrochemical industry. Desalination, Vol. 235, No. 1-3, (January 2009), pp.199-244, ISSN 0011-9164.

Rubio, J. Souza, M.L., Smith, R.W. (2002). Overview of flotation as a wastewater treatment technique. Minerals Engineering, Vol.15, No. 3, (March 2002), pp. 139-155, ISSN 0892-6875.

Santiago, V.M.J. (2009). Avaliação de Biorreator com membranas (MBR) no tratamento e reúso de efluentes da Petrobras. Apresentação para o Simpósio de Processo de Separação com Membranas, (July 23, 2009).

Scholz, W., Fuchsm, W. (2000). Treatment of oil contaminated wastewater in a membrane bioreactor. Water Research, Vol. 34, No. 14, (October 2000), pp. 3621-3629, ISSN $0043-$ 1354 .

Teodosiu, C.; Kennedy, M.D.; Van Straten, H.A.; Schippers, J.C. (1999) Evaluation of secondary refinery effluent treatment using ultrafiltration membranes. Water Research, Vol. 33, No. 9, (June 1999), pp. 2172-2180, ISSN 0043-1354.

Torres, A.P.R.; Santiago, V.M.J.; Borges, C.P. (2008). Performance evaluation of submerged membrane bioreactor pilot units for refinery wastewater treatment. Environmental progress, Vol. 17, No. 2, (July 2008), pp.189-194, ISSN 1944-7442.

Viero, A.F.; Melo, T.M.; Torres, A.P.R.; Ferreira, N.R. Sant'Anna, G.L.; Borges, C.P.; Santiago, V.M.J. (2008). The effects of long-term feeding of high organic loading in a submerged membrane bioreactor treating oil refinery wastewater. Journal of Membrane Science, Vol. 319, No. 1-2, (July 2008), pp. 223 - 230, ISSN 0376-7388.

Wagner, J. (2001). Membrane Filtration Handbook Practical tips and hints, 2nd ed., Osmonics Inc, Minnetonka.

Wang, Y.P., Smith, R. (1994). Wastewater minimization. Chemical Engineering Science, Vol. 49, No. 7, (April 1994), pp. 981-1006, ISSN 0009-2509.

Worrell, E., Galitsky, C. (2005). Energy Efficiency Improvement and Cost Saving Opportunities for Petroleum Refineries - An Energy Star Guide for Energy and Plant Managers, Ernest Orlando Lawrence. Berkeley National Laboratory (February 2005).

Yang, C. (2007). Electrochemical coagulation for oily water demulsification. Separation Purification Technology, Vol. 54, No. 3, (May 2007), pp. 388-395, ISSN 1383-5866. 


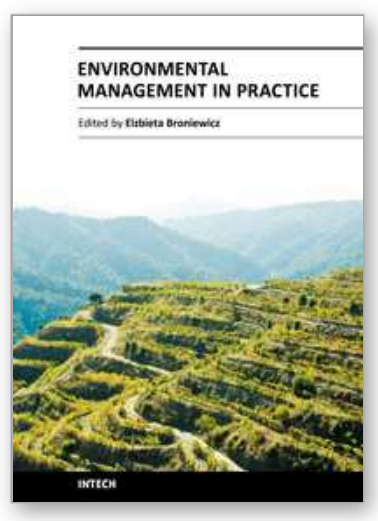

\section{Environmental Management in Practice}

Edited by Dr. Elzbieta Broniewicz

ISBN 978-953-307-358-3

Hard cover, 448 pages

Publisher InTech

Published online 21, June, 2011

Published in print edition June, 2011

In recent years the topic of environmental management has become very common. In sustainable development conditions, central and local governments much more often notice the need of acting in ways that diminish negative impact on environment. Environmental management may take place on many different levels - starting from global level, e.g. climate changes, through national and regional level (environmental policy) and ending on micro level. This publication shows many examples of environmental management. The diversity of presented aspects within environmental management and approaching the subject from the perspective of various countries contributes greatly to the development of environmental management field of research.

\section{How to reference}

In order to correctly reference this scholarly work, feel free to copy and paste the following:

Felipe Pombo, Alessandra Magrini and Alexandre Szklo (2011). Technology Roadmap for Wastewater Reuse in Petroleum Refineries in Brazil, Environmental Management in Practice, Dr. Elzbieta Broniewicz (Ed.), ISBN: 978-953-307-358-3, InTech, Available from: http://www.intechopen.com/books/environmental-management-inpractice/technology-roadmap-for-wastewater-reuse-in-petroleum-refineries-in-brazil

\section{INTECH}

open science | open minds

\section{InTech Europe}

University Campus STeP Ri

Slavka Krautzeka 83/A

51000 Rijeka, Croatia

Phone: +385 (51) 770447

Fax: +385 (51) 686166

www.intechopen.com

\section{InTech China}

Unit 405, Office Block, Hotel Equatorial Shanghai

No.65, Yan An Road (West), Shanghai, 200040, China

中国上海市延安西路65号上海国际贵都大饭店办公楼405单元

Phone: +86-21-62489820

Fax: +86-21-62489821 
(C) 2011 The Author(s). Licensee IntechOpen. This chapter is distributed under the terms of the Creative Commons Attribution-NonCommercialShareAlike-3.0 License, which permits use, distribution and reproduction for non-commercial purposes, provided the original is properly cited and derivative works building on this content are distributed under the same license. 